\title{
Molt and reproduction of the European green crab Carcinus maenas (Decapoda: Portunidae) in Patagonia, Argentina
}

\author{
Julio H. Vinuesa \\ Universidad Nacional de la Patagonia San Juan Bosco - CONICET. Ciudad Universitaria, Km 4 (9000), Comodoro \\ Rivadavia, Chubut, Argentina; jvinuesa@speedy.com.ar
}

\author{
Received 14-X-2005. C Corrected 14-VI-2006. $\quad$ Accepted 16-III-2007.
}

\begin{abstract}
The green crab Carcinus maenas, a decapod crustacean native to the northeastern Atlantic, has been invading distant areas, mainly for the last 25 years. This species is currently distributed along the coasts of the northeastern Pacific, South Africa, Japan, South Australia, Tasmania, and western and eastern North America, among others. Here we provide information on the biology of the green crab occurring in the central area of San Jorge Gulf, Argentina, where it has been established since 1999-2000. Crabs of both sexes were hand-collected between January 2004 and May 2005 from the intertidal zone and the upper sublittoral fringe. Sex, carapace width and molting stage were recorded. The reproductive status of males was based on the presence of sperm and spermatophores in testes and deferent ducts, and that of females on ovarian development and presence-absence of eggs. Stages of embryonic development for ovigerous females were also recorded. The most important physiological events taking place during the annual cycle of the adult population were as follows: (1) male molt occurred mainly in November and female molt between January and the beginning of March; (2) the reproductive season started in January, after a courtship in which the male, larger in size, holds the female until the molt, and spermatophores are ejaculated once the old exoskeleton is cast off; (3) females left the intertidal zone early and moved to lower littoral levels during fall and winter; (4) larvae appeared in September. Rev. Biol. Trop. 55 (Suppl. 1): 49-54. Epub 2007 June, 29.
\end{abstract}

Key words: molt, reproductive biology, green crab, Carcinus maenas.

The European green crab, Carcinus maenas (Linnaeus 1758) is a coastal species, native to the European Atlantic and northwest Africa, being distributed from Mauritania to Norway (Jamieson et al. 2002). The species has spread northwards and southwards, and has been recorded in eastern North America and South Australia, although permanent populations were unlikely to become established in some locations (Carlton and Cohen 2003). However, a global dispersion has been taking place for the last 25 years to areas as distant as Japan (Sakai 1986), western North America (Cohen et al. 1995), South Africa (Le Roux et al. 1990), and the Patagonian Atlantic coast. In regard to the latter, the species was found along the central coasts of San Jorge Gulf (4555' S) in 2001 (Vinuesa 2005), and in Camarones Bay, north to San Jorge Gulf (approximately 4454' S), in 2003 (Hidalgo et al. 2005). These findings coincided with substantial changes in the geographical distribution of several fish and crustacean species of warm-temperate waters (Góngora et al. 2003, Vinuesa 2005) that have been present in the typically cold-temperate waters of San Jorge Gulf over the last years.

The C. maenas population of San Jorge Gulf is at the southern limit of the species' geographical distribution, which determines the importance of studying the main physiological events and their temporal occurrence to 
elucidate adaptive features to coastal waters of the southern hemisphere.

In the northern hemisphere, the annual cycle of $C$. maenas has been examined in detail in the European Atlantic Ocean (KleinBreteler 1975a,b, 1976a,b, Van der Meeren 1992, d'Udekem d'Acoz 1993, Quieroga 1996), and in the northwestern Atlantic Ocean (Berril 1982).

\section{MATERIALS AND METHODS}

The study area is located in the central coast of San Jorge Gulf in the southwestern Atlantic Ocean, from about $45^{\circ}$ to $47^{\circ} \mathrm{S}$. Green crabs were hand-collected from Punta del Marqués, south of Comodoro Rivadavia City, Chubut Province, Argentina (ca. 455'ㅇ' S). In the study area, sea surface temperatures range from a mean minimum of $7.3^{\circ} \mathrm{C}$ in August to a mean maximum of $16.2{ }^{\circ} \mathrm{C}$ in February (Fig.1) (Anonymous 2005). Salinity ranges from about 33 to 34 ppt (Akselman 1996), with higher variations in certain coastal areas. There are unequal semi-diurnal tides with maximum amplitudes of $6 \mathrm{~m}$.
Four green crab couples were found mating in the intertidal in January 2004, and after this event, individuals were sampled monthly during low tides until May 2005. Due to the null or reduced captures in the area, females, which are better indicators of the reproductive cycle than males, were collected from northern locations of Comodoro Rivadavia.

Carapace width (CW), and length and height of the right cheliped were measured using a digital caliper with a precision of $0.1 \mathrm{~mm}$.

In females, the presence or absence of eggs on the pleopods and signs of prior hatching (such as empty egg cases) were recorded. Thus, females were classified as being ovigerous (OVI), non-ovigerous (NOV) or post-ovigerous (POV). Embryonic development was divided into the following four stages: (I) lack of development, no visible embryo; (II) embryo visible as a whitish body without pigmentation; (III) beginning of ocular pigmentation and appearance of chromatophores on the embryo; (IV) welldeveloped embryo with scarce yolk, close to hatching. A macroscopic analysis of the ovary was done to determine the stage of ovarian maturity, and the following three stages were

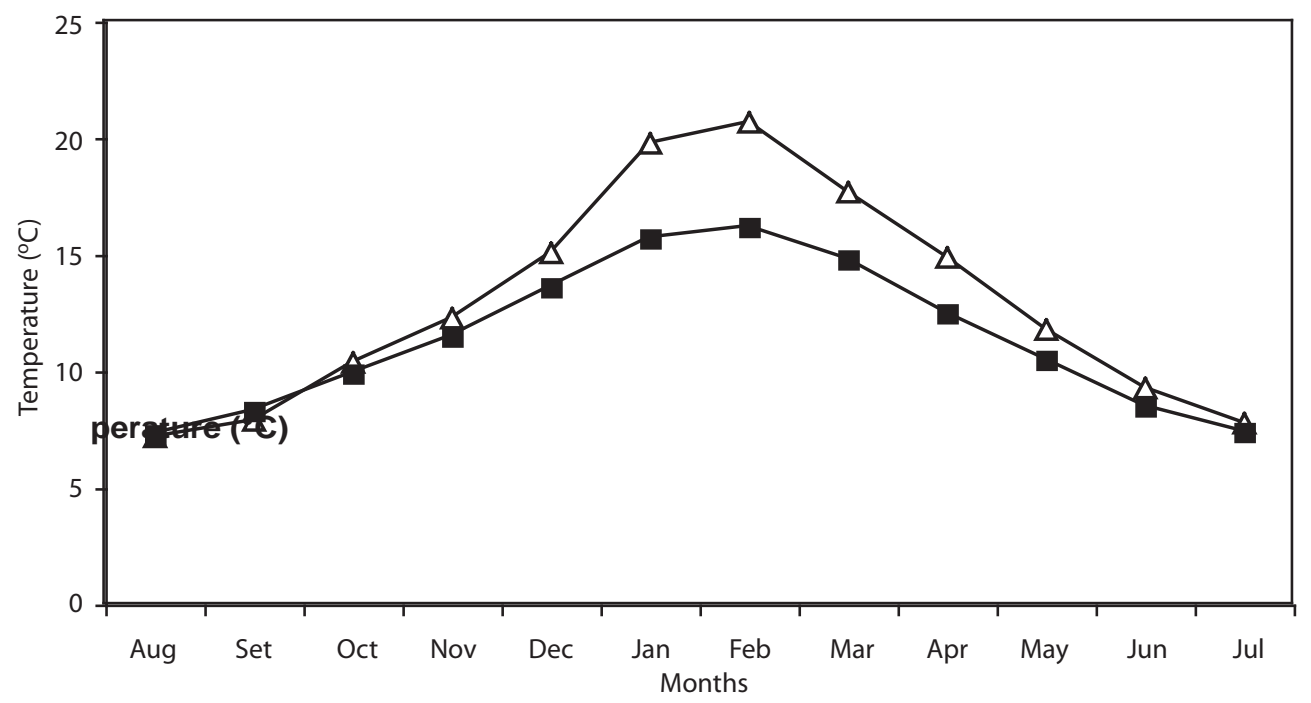

Fig. 1. Historic annual average temperatures in Comodoro Rivadavia (black symbol) obtained from the Servicio de Hidrografía Naval, and average temperatures registered near Punta del Marqués during 2003-2004 (white symbol). 
discriminated: (a) immature: non-vitellogenic, reduced ovary; (b) advanced development: after the beginning of the secondary vitellogenesis; and (c) mature: very well-developed and colored ovary, with apparently mature oocytes.

In males, the testes and deferent ducts were examined to verify the presence of sperm and spermatophores. A male was considered to be adult when the deferent ducts were filled with stored spermatophores. No morphometric studies were done because of the reduced size of the samples and the small size intervals of crabs.

Crabs were classified according to their molting stage as follows: (a) Intermolt stage (INT): crab with a hard carapace and generally with epizoic organisms on the carapace and/or appendages; (b) pre-molt stage (PRE): crab with a new shell growing under the old one or undergoing molting; and (c) postmolt stage (POS): crab with a soft, bright colored shell and without epibiosis.
Most of the crabs were fixed in a $7 \%$ formaldehyde solution in sea water and a few in $95 \%$ ethanol. Crabs caught were not returned to the sea due to the invasive character of the species.

\section{RESULTS}

A total of 84 crabs (59 males and 25 females) were collected after intensive search throughout the study. In Punta del Marqués, no crabs were found between February and May 2005, and no juveniles were detected during the entire sampling period. Crabs were always encountered under rocks in tide-pools: females were encountered at subtidal levels during fall and winter. The size varied between 49.0 and $73.4 \mathrm{~mm}$ CW (males) and 31.2 and $64.3 \mathrm{~mm}$ CW (females). The characteristics of females are shown in Table 1.

TABLE 1

Characteristics of females in San Jorge Gulf, Argentina.

\begin{tabular}{|c|c|c|c|c|c|}
\hline Date & CW & Sexual stage & Embryo stage & Ovary stage & Molt stage \\
\hline $21 / 01 / 04$ & 51.0 & POV & --- & Mature & POS \\
\hline$”$ & 43.9 & POV & --- & Mature & PRE \\
\hline$”$ & 49.4 & $\mathrm{NOV}$ & --- & Mature & PRE \\
\hline ” & 56.2 & POV & --- & Mature & POS \\
\hline $21 / 02 / 04$ & 53.5 & POV & --- & Mature & INT \\
\hline$”$ & 58.1 & POV & --- & Mature & POS \\
\hline $27 / 02 / 04$ & 59.6 & POV & --- & Mature & POS \\
\hline$”$ & 61.1 & POV & --- & Mature & INT \\
\hline 08/03/04 & 62.9 & $\mathrm{NOV}$ & --- & Mature & POS \\
\hline $27 / 03 / 04$ & 42.0 & NOV & --- & Immature & INT \\
\hline $26 / 05 / 04$ & 49.7 & OVI & I & Adv.Dev. & INT \\
\hline$"$ & 59.8 & OVI & I & Adv.Dev. & INT \\
\hline $27 / 06 / 04$ & 48.9 & OVI & II & Adv.Dev. & INT \\
\hline $25 / 07 / 04$ & 53.6 & OVI & III & Adv.Dev. & INT \\
\hline $16 / 08 / 04$ & 64.3 & OVI & IV & Adv.Dev. & INT \\
\hline$”$ & 56.8 & OVI & IV & Adv.Dev. & INT \\
\hline $12 / 09 / 04$ & 52.3 & OVI & IV & Adv.Dev. & INT \\
\hline$"$ & 57.7 & OVI & IV & Adv.Dev. & INT \\
\hline 25/09/04 & 45.8 & $\mathrm{NOV}$ & --- & Adv.Dev. & INT \\
\hline $26 / 10 / 04$ & 53.8 & POV & --- & Adv.Dev. & INT \\
\hline $22 / 11 / 04$ & 49.0 & POV & --- & Adv.Dev. & INT \\
\hline $10 / 12 / 04$ & 57.2 & POV & --- & Mature & INT \\
\hline $16 / 01 / 05$ & 46.4 & $\mathrm{NOV}$ & --- & Mature & INT \\
\hline $16 / 02 / 05$ & 31.3 & $\mathrm{NOV}$ & --- & Immature & INT \\
\hline$”$ & 52.7 & POV & --- & Mature & INT \\
\hline
\end{tabular}


In 2004 (between the end of January and the beginning of March) six couples were found mating. All males were larger than females and in intermolt stage. Three of the females had molted recently, while the others were postovigerous in premolt stage. Only one of the three molted females had been impregnated, but no spawning was observed.

Ovigerous females were caught from May 2004 onwards, all in small numbers. Females were neither collected in April 2004, nor between March and May 2005. In September 2004, two females carried embryos, which hatched in the laboratory 10 days later. All females captured after September 2004 were post-ovigerous, except for one immature individual found in February 2005.

Despite the few females collected, it was possible to estimate the approximate size at which sexual maturity is reached in the study area. Adult females were larger than $50 \mathrm{~mm}$ $\mathrm{CW}$; females measuring less than this size were two immature females of 31.3 and $42 \mathrm{~mm} \mathrm{CW}$, four adults between 43.9 and $49.7 \mathrm{~mm} \mathrm{CW}$, and females that seemed to be at first sexual maturity (small size, mature ovaries and eggs without signs of hatching) of 45.8, 46.4 and 49.4 mm CW (Table 1).

Embryos developed gradually from May to September, when they were near hatching (Table 1). Ovaries developed slowly after egg laying; the beginning of the secondary or lipidic vitellogenesis occurred in May or June, and maturity was reached the next summer.

Spermatophores were present in the deferent ducts of all males. Deferent ducts were distended with spermatophores by the end of the year. In November 2004, two adult males had molted recently and three adult males were at the postmolt stage. One male in March and another one in April 2004 were found in early post-molt.

\section{DISCUSSION}

C. maenas is an eurythermic and euryhaline species, capable of tolerating salinities up to 17 ppt during larval stages (Jamieson et al. 1998). Hidalgo et al. (2005) described the optimum thermal range for the development of both native and introduced populations of $C$. maenas. Based on this information, San Jorge Gulf waters with minimum mean temperatures of 7.0-8. ${ }^{\circ} \mathrm{C}$ and maximum mean temperatures of 14.6-16.8 ${ }^{\circ} \mathrm{C}$ provide the appropriate conditions for the development of the species.

The temperature is the main limiting factor for the distribution of $C$. maenas because it affects directly the life cycle by influencing the survival of the larvae, juveniles and adults, or indirectly by influencing the development of reproductive organs and embryos. Repeated reproduction failures may hinder the establishment of invasive species. However, this does not seem to be the case for the studied green crab population, since surface temperatures recorded during 2003-2004 in the sampling area were above the historical average (Fig. 1), thereby favoring successful mating.

Our results suggest that the $C$. maenas population is undergoing growth and development, but the absence of juveniles after 2002 may indicate recruitment failure, at least in Punta del Marqués area.

The reproductive behavior observed in the study area is similar to that described for other green crab populations (Berril and Arsenault 1982, Van der Meeren 1992). Considering the fact that adult green crab females molt during mating, and that a subsequent molt is unlikely to occur before egg-laying or while carrying eggs, it is reasonable to assume that they molt once a year.

Small non-ovigerous females with apparently mature ovaries could be adolescents becoming adults after molting. Female sexual maturity seems to be attained at about 40 to $50 \mathrm{~mm}$ CW, but larger sample sizes will be necessary to confirm this finding. In Maine, the minimum size at sexual maturity is $34 \mathrm{~mm} \mathrm{CW}$ (Berril 1982), and similar results are expected in San Jorge Gulf. The pairing may continue after spermatophore ejaculation, as observed in one of the couples.

Eggs were not extruded by females collected between January and March, which possibly implies that they are not laid immediately after impregnation. Egg-release may occur later in deeper waters. In Maine, the mating season 
lasts for three months, from mid-July to midOctober, and ovigerous females appear between April and July (Berril 1982), thus indicating a spermatophore retention time of about six to nine months until egg extrusion. In San Jorge Gulf, egg extrusion is likely to occur between April and May, when ovigerous females were first observed carrying eggs at stage I with no visible development.

In the northern hemisphere, the physiological events taking place during the annual reproductive cycle of the green crab have been described for Europe and northwestern America. In Ostend (Belgium), the population exhibits a prolonged reproductive period, and older females spawn two or three times during the same intermolt period, from winter to the beginning of summer (d’Udekem d'Acoz 1993). In Holland, there are two main peaks of egg production, one at the beginning of winter and the other between spring and the beginning of summer (Broekhuysen 1936). In the Wadden Sea, pelagic megalopae from two or three broods were observed between the end of June and November (Klein Breteler 1976b). Near Bergen (Norway), the fact that at the beginning of February $69 \%$ of females had mature eggs in their ovaries and most of the other individuals were ovigerous females suggests that in this locality eggs are laid between January and February (Van der Meeren 1992). In Maine, egg-laying occurs mainly between May and July (Berril 1982). The above information reveals that the reproductive period of the green crab is longer in warmer than in cold-temperate waters, with multiple spawnings in the former and a single one in the latter, as observed in San Jorge Gulf.

The duration of embryonic development is also temperature dependent. In San Jorge Gulf this period lasts for about four months, between May and September. In Maine, embryogenesis lasts about three or four months, as estimated by the time of appearance of ovigerous females and megalopae, and the entire developmental period of pelagic larvae, which ranges from 40 to 50 days.

The process of green crab migration in the littoral zone has been described for European coasts. Adult crabs, mainly ovigerous females, migrate to deeper waters with more stable environmental conditions during winter (Broekhuysen 1936, Edwards 1958, Van der Meeren 1992). A similar behavior was observed in the study area, where females left the intertidal zone and moved to lower littoral levels after mating.

In terms of reproductive cycle and molt, the green crab population in San Jorge Gulf appears to be well adapted to the oceanographic conditions in the southern hemisphere. Larval hatching occurred in spring, coinciding with a period of high plankton production, which is relevant for the development of the different pelagic larval stages of the species.

\section{ACKNOWLEDGEMENTS}

This study has been granted by the Consejo Nacional de Investigaciones Científicas y Técnicas (CONICET) of Argentina, PIP $\mathrm{N}^{\circ}$ 02566. I appreciate the help of Silvia Pietrocovski in the translation of the manuscript.

\section{RESUMEN}

El cangrejo verde europeo es un crustáceo decápodo originario del Océano Atlántico nororiental, el cual principalmente en los últimos 25 años ha invadido, entre otros, el Pacífico nororiental, Sudáfrica, Japón, sur de Australia, Tasmania y ambas costas de América del Norte. Aquí resumimos las observaciones biológicas en el área central del Golfo San Jorge, Argentina, donde este cangrejo se ha instalado a partir de 1999 ó 2000. Recolectamos manualmente muestras de ambos sexos entre enero de 2004 y mayo de 2005 en el intermareal y la franja superior del sublitoral. La muda de los machos ocurre principalmente en noviembre y la de las hembras, entre enero y principios de marzo. La época reproductiva se inicia en enero, con un cortejo previo donde el macho, de mayor talla que la hembra, la retiene hasta la muda y, una vez desprendido el viejo exoesqueleto, se produce la eyaculación de los espermatóforos. Las hembras abandonan tempranamente el intermareal y migran a niveles inferiores del litoral durante el otoño e invierno, eclosionando las larvas en setiembre.

Palabras clave: muda, biología reproductiva, cangrejo verde, Carcinus maenas. 


\section{REFERENCES}

Akselman, R. 1996. Estudios ecológicos en el Golfo San Jorge y adyacencias (Atlántico Sudoccidental). Distribución, abundancia y variación estacional del fitoplancton en relación a factores físico-químicos y a la dinámica hidrológica. Tesis Doctoral, Universidad de Buenos Aires, Buenos Aires, Argentina. 319 p.

Berril, M. 1982. The life cycle of the green crab Carcinus maenas at the northern end of its range. J. Crust. Biol. 2: 31-39.

Berril, M. \& M. Arsenault. 1982. Mating behavior of the green shore crab Carcinus maenas. Bull. Mar. Sci. 32: 632-638.

Broekhuysen, G.J. 1936. On development, growth and distribution of Carcinides maenas (L.). Arch. Neérland. Zool. 2: 57-399.

Carlton, J.T. \& A.N. Cohen. 2003. Episodic global dispersal in shallow water marine organisms: the case history of the European crabs Carcinus maenas and C. aestuarii. J. Biogeogr. 30: 1809-1820.

Cohen, A.N., J.T. Carlton \& M.C. Fountain. 1995. Introduction, dispersal and potential impacts of the green crab Carcinus maenas in San Francisco Bay, California. Mar. Biol. 122: 225-237.

Edwards, R.L. 1958. Movements of individual crabs in a population of the shore crab Carcinus maenas L., in the littoral zone. J. Animal Ecol. 27: 37-45.

d’Udekem d'Acoz, C. 1993. Activites reproductrices saisonnieres des diferentes classes de tailles d'une population de crabes verts Carcinus maenas (Linnaeus, 1758) dans le sud de la Mer du Nord. Cah. Biol. Mar. 35: 1-13.

Góngora, M.E., N. Bovcon, P. Cochia \& A.E. Gosztonyi. 2003. Aportes al conocimiento de la ictiofauna del Golfo San Jorge. Res. V Jornadas Nacionales de Ciencias del Mar, Mar del Plata: p. 117.

Hidalgo, F.J., P.J. Barón \& J.M. Orensanz. 2005. A prediction comes true: the green crab invades the Patagonian coast. Biol. Invasions 7: 547-552.

Jamieson, G.S., M.G. Foreman, J.Y. Cherniawsky \& C.D. Levings. 2002. European green crab (Carcinus maenas) dispersal: the Pacific experience, p. 561-576. In A.J. Paul, E.G. Dawe, R.W. Elner, G.S. Jamieson, G.H. Kruse, R.S. Otto, B. Sainte-Marie, T.C. Shirley \& D. Eoodby (eds.). Crabs in Cold Water Regions: Biology, Management and Economics. Sea Grant
College Program, University of Alaska, Alaska, USA.

Jamieson, G.S., E.D. Grosholz, D.A. Armstrong \& R.W. Elner. 1998. Potential ecological implications from the introduction of the European green crab, Carcinus maenas (Linneus), to British Columbia, Canada, and Washington, USA. J. Nat. Hist. 32: 1587-1598.

Klein-Breteler, W.C.M. 1975a. Growth and molting of juvenile shore crabs, Carcinus maenas, in a natural population. Neth. J. Sea Res. 9: 86-99.

Klein-Breteler, W.C.M. 1975b. Laboratory experiments on the influence of environmental factors on the frequency of molting and the increase in size at molting of juvenile shore crabs, Carcinus maenas. Neth. J. Sea Res. 9: 100-120.

Klein-Breteler, W.C.M. 1976a. Migration of the shore crab, Carcinus maenas, in the Dutch Wadden Sea. Neth. J. Sea Res. 10: 338-353.

Klein-Breteler, W.C.M. 1976b. Settlement, growth and production of the shore crab, Carcinus maenas, on tidal flats in the Dutch Wadden Sea. Neth. J. Sea Res. 10: 354-376.

Le Roux P.J., G.M. Branch \& M.A.P. Joska. 1990. On the European distribution, diet and possible impact of the invasive European shore crab Carcinus maenas (L.) along the South African coast. S. Afr. J. Mar. Sci. 9: 85-93.

Quieroga, H. 1996. Distribution and drift of the crab Carcinus maenas (L.) (Decapoda: Portunidae) larvae over the continental shelf off northern Portugal in April, 1991. J. Plankton Res. 18: 1981-2000.

Sakai, T. 1986. Rare species and their genus of crabs in Japan. Res. Crust. 15: 1-4.

Van der Meeren, G.I. 1992. Location of spawning shore crabs, Carcinus maenas (L., 1758) (Decapoda: Brachyura). Crustaceana 63: 92-94.

Vinuesa, J.H. 2005. Distribución de crustáceos decápodos y estomatópodos del Golfo San Jorge, Argentina. Rev. Biol. Mar. Oceanogr. 40: 7-21.

\section{INTERNET REFERENCE}

Anonymous. 2005. Temperaturas de agua de mar en superficie $\left({ }^{\circ} \mathrm{C}\right)$. Comodoro Rivadavia (Downloaded: May 25, 2006, http://www.hidro.gov.ar/ceado/Ef/crivadav.asp). 